\title{
Pengaruh Penerapan Model Pembelajaran Critical Incident Terhadap Prestasi Belajar Siswa Pada Mata Pelajaran Aqidah Akhlak Kelas III MI NW Dames
}

\author{
${ }^{1}$ Elfa Yuliana \& ${ }^{\mathbf{2}}$ Ainul Hidayah \\ Institut Agama Islam Hamzanwadi NW Pancor \\ Email: elfayuliana@ymail.com
}

\begin{abstract}
Abstrak
Tujuan penelitian ini adalah untuk mengetahui penerapan model pembelajaran critical incident berpengaruh positif dan signifikan terhadap prestasi belajar siswa pada mata pelajaran aqidah akhlak kelas III MI NW Dames tahun pelajaran 2019/2020.

Penelitian ini merupakan penelitian kuantitatif. Desain penelitian yang digunakan adalah Quasi Eksperimental Design (eksperimen semu) dengan menggunakan model Non Equivalen Control Group Design. Teknik pengumpulan data dengan menggunakan tes pilihan ganda. Populasi dalam penelitian ini adalah kelas III MI NW Dames, dan sampel penelitian ini adalah kelas III $^{\mathrm{A}}$ sebagai kelas eksperimen dan kelas III $^{\mathrm{B}}$ sebagai kelas kontrol. Teknik analisis yang digunakan untuk uji hipotesis adalah uji-t.

Hasil analisis menunjukkan bahwa perbedaan rata-rata skor prestasi belajar Akidah Akhlak kelas eksperimen dan kelas kontrol yaitu $\mathrm{X}=83,73>\mathrm{X}=$ 72,73. Dengan menggunakan uji-t diperoleh hasil $t_{\text {hitung }}=2,857>t_{\text {tabel }}(0,05)=2,048$, dengan taraf signifikansi $5 \%(0,05)$ dan $\mathrm{dk}\left(\mathrm{n}_{1}+\mathrm{n}_{2}-2=15+15-2\right)=28$, maka $\mathrm{H}_{\mathrm{o}}$ ditolak dan $\mathrm{H}_{\mathrm{a}}$ diterima, itu berarti model pembelajaran critical incident berpengaruh positif dan signifikan terhadap prestasi belajar aqidah akhlak siswa kelas III MI NW Dames tahun pelajaran 2019/2020. Dengan demikian dapat disimpulkan bahwa terdapat perbedaan yang positif dan signifikan prestasi belajar aqidah akhlak siswa antara kelas siswa yang menggunakan model pembelajaran critical incident (kelas $\mathrm{III}^{\mathrm{A}}$ ) dan kelas siswa yang menggunakan model pembelajaran yang konvensional $\left(\right.$ kelas $\left.\mathrm{III}^{\mathrm{B}}\right)$.
\end{abstract}

Kata Kunci: Model Pembelajaran, Critical Incident, Prestasi Belajar Siswa. 


\section{PENDAHULUAN}

Model pembelajaran adalah kerangka konseptual/operasional, yang melukiskan prosedur yang sistematis dalam mengorganisasikan pengalaman belajar untuk mencapai tujuan belajar tertentu dan berfungsi sebagai pedoman bagi para pengajar dalam merencanakan dan melaksanakan aktivitas pembelajaran. ${ }^{1}$ Model pembelajaran ini sangat penting dalam proses belajar mengajar di lembaga pendidikan. Apabila proses pendidikan tidak menggunakan model pembelajaran yang tepat maka akan sulit untuk mendapatkan tujuan pembelajaran yang diharapkan. Maka dari itu diperlukan suatu model pembelajaran yang benar-benar tepat.

Namun kebanyakan guru di SD/MI saat ini khususnya pada pembelajaran Aqidah Akhlak yang telah dilaksanakan masih didominasi oleh penggunaan metode ceramah atau metode yang masih konvensional yang kegiatannya lebih berpusat pada guru. Dalam hal ini tentu saja aktivitas siswa dapat dikatakan hanya mendengarkan penjelasan guru, mencatat hal-hal yang dianggap penting sehingga siswa cenderung dituntut untuk membenarkan apa yang dikatakan oleh guru tanpa usaha untuk membuktikan kebenarannya. Akibatnya siswa bersifat pasif dan guru kurang memberi kesempatan kepada siswa untuk berpikir memecahkan masalah.

Berdasarkan observasi dan wawancara dengan guru kelas III MI NW Dames pada mata pelajaran Aqidah Akhlak tahun pelajaran 2019/2020 menunjukkan bahwa proses pembelajarannya masih belum dapat terlaksana dengan baik atau masih kurang optimal, serta prestasi belajar siswa yang telah dicapai masih rendah, dilihat dari nilai ulangan rata-rata siswa, dimana lebih dari $50 \%$ siswanya belum mencapai nilai yang sesuai dengan KKM (Kriteria Ketuntasan Minimum) yang telah ditentukan oleh sekolah yaitu 70. Untuk lebih jelasnya dapat dilihat pada tabel dibawah ini:

Tabel 1.1 Nilai Rata-Rata UAS Siswa Kelas III September-Desember Tahun 2019

\footnotetext{
${ }^{1}$ Hosnan, Pendekatan Saintifik dan Kontekstual dalam Pembelajaran Abad 21, (Bogor: Ghalia Indonesia, 2014), hlm. 337
} 


\begin{tabular}{|c|c|c|c|}
\hline Kelas & KKM & Nilai Rata-Rata & Jumlah siswa \\
\hline III A & 70 & 65,0 & 17 \\
\hline III B & 70 & 65,0 & 15 \\
\hline
\end{tabular}

Dari data di atas terlihat bahwa nilai rata-rata pelajaran Aqidah Akhlak masih rendah yaitu 65,0. Hal ini dapat dilihat juga dari data hasil ulangan siswa pada setiap pokok bahasan yang menunjukkan masih banyaknya yang belum mencapai KKM (kriteria ketuntasan minimum). Sedangkan rendahnya prestasi belajar siswa dapat dilihat dari proses pembelajarannya yang masih belum berani mengungkapkan pendapatnya atau bertanya, siswa kurang memperhatikan penjelasan guru, siswa kurang aktif dalam menerima pelajaran dan ada juga siswa yang masih suka bermain-main ketika guru sedang menjelaskan pelajaran.

Hal yang menjadi hambatan selama ini dalam pembelajaran Aqidah Akhlak adalah disebabkan kurang dikemasnya pembelajaran Aqidah Akhlak dengan model yang menarik, menantang dan menyenangkan. Dan mereka belum bisa menghubungkan antara apa yang mereka pelajari dan bagaimana pengetahuan itu akan digunakan. Hal ini dikarenakan cara mereka memperolah informasi dan motivasi diri belum tersentuh oleh model yang betul-betul bisa membantu mereka. Karena seorang guru seringkali menyampaikan materi Aqidah Akhlak dengan menggunakan metode ceramah, sehingga pembelajaran Aqidah Akhlak cenderung membosankan dan kurang menarik minat siswa, yang pada akhirnya prestasi belajar siswa kurang memuaskan. Oleh karena itu diperlukan suatu model yang benar-benar bisa memberi jawaban dari masalah ini. Salah satu model yang bisa lebih memberdayakan siswa adalah model Critical Incident (pengalaman penting).

Pembelajaran dengan model Critical Incident (pengalaman penting) lebih memberdayakan dan membantu siswa dapat mengembangkan kepribadiannya dan membantu siswa memahami teori secara mendalam melalui pengalaman belajar, serta menerapkannya dalam kehidupan sehari-hari. Model Critical Incident (pengalaman penting) suatu model yang mana siswa harus mengingat dan mendiskripsikan pengalaman masa lalunya yang menarik dan berhubungan serta 
berkaitan dengan pokok bahasan yang akan disampaikan, lalu guru menyampaikan materi dengan menghubungkan pengalaman yang dimiliki oleh siswanya. $^{2}$

Model pembelajaran critical incident sangat cocok diterapkan bagi siswa SD/MI terutama pada kelas III, karena selain untuk melatih berbicara, pembelajaran ini juga dapat mengaitkan antara pengalaman siswa dengan materi yang akan dipelajari serta membuat siswa lebih aktif dalam pembelajaran.

Berdasarkan uraian di atas, maka peneliti bermaksud melakukan penelitian yang berjudul "Pengaruh Penerapan Model Pembelajaran Critical Incident (Pengalaman Penting) terhadap Prestasi Belajar Siswa Pada Mata Pelajaran Aqidah Akhlak Kelas III MI NW Dames Pokok Bahasan Akhlak yang Terpuji Tahun Pelajaran 2019/2020”.

\section{A. Rumusan Masalah}

Berdasarkan latar belakang, identifikasi masalah di atas, maka peneliti dapat merumuskan masalah penelitian sebagai berikut: Apakah terdapat Pengaruh Penerapan Model Pembelajaran Critical Incident (Pengalaman Penting) terhadap Prestasi Belajar Siswa Pada Mata Pelajaran Akidah Akhlak Kelas III MI NW Dames Pokok Bahasan Akhlak yang Terpuji?

\section{B. Tujuan Penelitian}

Sesuai dengan latar belakang masalah dan rumusan masalah, maka tujuan penelitian ini adalah untuk mengetahui Pengaruh Penerapan Model Pembelajaran Critical Incident (Pengalaman Penting) terhadap Prestasi Belajar Siswa Pada Mata Pelajaran Akidah Akhlak Kelas III MI NW Dames Pokok Bahasan Akhlak yang Terpuji Tahun Pelajaran 2019/2020.

2 https://syaharuddin.wordpress.com/2008/04/25/mengurangi-kebosanan-siswa-melaluiberbagai-metode-mengajar/, diakses 02 Juli 2019 


\section{LANDASAN TEORI}

\section{A. Deskripsi Teoritis}

\section{Model Pembelajaran Critical Incident}

a. Pengertian Model Pembelajaran Critical Incident

Model ini merupakan proses pembelajaran yang dikembangkan dengan paradigma pedagogik reflektif yang lebih mengutamakan aktivitas siswa. Strategi ini bertujuan untuk membantu siswa menemukan dan memaknai pengalamannya sendiri dalam menerima dan mengamalkan nilainilai dan ajaran agama dalam kehidupan sehari-hari.

Critical Incident (Pengalaman Penting) suatu model yang mana siswa harus mengingat dan mendeskripsikan pengalaman masa lalunya yang menarik dan berhubungan serta berkaitan dengan pokok bahasan yang akan disampaikan, lalu guru menyampaikan materi dengan menghubungkan pengalaman yang dimiliki oleh siswanya. ${ }^{3}$

Jadi dapat disimpulkan model pembelajaran Critical Incident adalah model yang digunakan oleh pendidik dengan maksud mengajak peserta didik untuk mengingat pengalaman yang pernah dijumpai atau dialami sendiri kemudiaan dikaitkan dengan materi bahasan.

b. Tujuan Model Pembelajaran Critical Incident

Setiap model pasti mempunyai tujuan masing-masing, adapun tujuan dari model critical incident (pengalaman penting) ialah untuk melibatkan peserta didik aktif sejak dimulainya pembelajaran dengan meminta peserta didik untuk mengungkapkan pengalaman yang mereka miliki. ${ }^{4} \mathrm{Hal}$ ini juga serupa dengan apa yang di tulis Ahmad Sabri dalam bukunya model belajar mengajar dan micro teaching bahwa model ini mempunyai tujuan untuk melihat siswa sejak awal dengan melihat pengalaman mereka. ${ }^{5}$

\footnotetext{
${ }^{3}$ http :/syaharuddin. Wordpress.com/2008/04/25/mengurrangi kebosanan siswa melalui berbagai metode mengajar, diakses 06 Juli 2019

${ }^{4}$ Dede Rosyada, Pendidikan Kewargaan, (Jakarta: Prenada Media,2004 ), hlm. 25

${ }^{5}$ Ahmad Sabri, Strategi Belajar Mengajar dan Micro Teaching, (Ciputat: Quantum Teaching, 2005), hlm. 122
} 
c. Langkah-langkah Model Pembelajaran Critical Incident

1) Sampaikan kepada siswa topik atau materi yang akan dipelajari dalam pertemuan hari itu.

2) Berilah kesempatan beberapa menit kepada siswa untuk mengingat-ingat pengalaman mereka yang tidak terlupakan berkaitan dengan materi yang ada.

3) Tanyakan pengalaman apa yang menurut mereka tidak terlupakan.

4) Sampaikan pembelajaran dengan mengaitkan pengalaman-pengalaman siswa dengan materi yang akan anda sampaikan.

5) Dari jawaban-jawaban yang muncul, guru bisa memulai pelajaran dengan mengaitkan pengalaman siswa dengan topik yang diajarkan. ${ }^{6}$

d. Manfaat Model Pembelajaran Critical Incident

1) Siswa dapat lebih aktif dalam pembelajaran .

2) Seorang guru dapat melihat kemampuan siswa sejak awal dengan melihat pengungkapkan pengalaman yang mereka miliki.

3) Dengan model pembelajaran critical incident siswa dituntut untuk tidak malu untuk berbicara di dalam kelas. ${ }^{7}$

2. Pembelajaran Aqidah Akhlak

Mata pelajaran Aqidah Akhlak ini merupakan cabang dari pendidikan agama Islam, menurut Zakiyah Drajat pendidikan agama Islam adalah suatu usaha untuk membina dan mengasuh peserta didik agar senantiasa dapat memahami ajaran Islam secara menyeluruh. Lalu menghayati tujuan yang pada akhirnya dapat mengamalkan serta menjadikan Islam sebagai pandangan hidup. $^{8}$

Aqidah berasal dari bahasa Arab yang diambil dari kata dasar, secara etimologi (bahasa) akidah berasal dari kata “aqada-ya'qidu-aqdan", berarti

\footnotetext{
${ }^{6}$ Hosnan, Pendekatan Saintifik dan Kontekstual dalam Pembelajaran Abad 2, (Bogor: Ghalia Indonesia , cet. I, 2014), hlm. 230

${ }^{7}$ http://www.academia.edu/30501994/INCIDENT_CRITICAL, diakses 14 Juli 2019

8 Abdul Majid dan Dian Andayani, Pendidikan Agama Islam Berbasis Kompetensi (Konsep Implementasi Kurikulum 2004), (Bandung: Remaja Rosda Karya, 2005), hlm. 130
} 
ikatan perjanjian, sangkutan dan kokoh. ${ }^{9}$ Artinya sesuatu yang menjadi tempat hati yang mana hati terikat kepadanya. ${ }^{10}$

Sedangkan menurut istilah keyakinan atau kepercayaan terhadap sesutau yang dalam setiap hati seseorang yang membuat hati senang. Dalam Islam aqidah ini kemudian melahirkan iman, menurut Al-Ghozali, sebagai mana dikutip oleh Hamdani Ihsan dan A. Fuad Ihsan, iman adalah mengucapkan dengan lidah mengakui kebenarannya dengan hati dan mengamalkan dengan anggota. ${ }^{11}$

a. Tujuan Pembelajaran Aqidah Akhlak di MI

Mata pelajaran Aqidah Akhlak di Madrasah Ibtidaiyah bertujuan untuk membekali peserta didik agar dapat:

1) Memupuk dan mengembangkan dasar ketuhanan yang sejak lahir. Dengan naluri ketuhanan, manusia berusaha untuk mencari Tuhannya, kemampuan akal dan ilmu yang berbeda-beda memungkinkan manusia akan keliru mengerti Tuhan. Dengan aqidah akhlak, naluri atau kecenderungan manusia akan keyakinan adanya Tuhan Yang Maha Kuasa dapat berkembang dengan benar

2) Aqidah akhlak bertujuan pula membentuk pribadi muslim yang luhur dan mulia. Seorang muslim yang berakhlak mulia senantiasa bertingkah laku terpuji, baik ketika berhubungan dengan Allah, dengan sesama manusia, makhluk lainnya serta dengan alam lingkungan. Oleh karena itu, perwujudan dari pribadi muslim yang luhur berupa tindakan nyata menjadi tujuan dalam aqidah akhlak.

3) Menghindari diri dari pengaruh akal pikiran yang menyesatkan. Manusia diberi kelebihan oleh Allah dari makhluk lainnya berupa akal pikiran.

\footnotetext{
${ }^{9}$ H. Mahmud Yunus, Kamus Arab-Indonesia, (Jakarta: PT Hidakarya Agung, 1972), hlm. 274

${ }^{10}$ A. Zainuddin dan M. Jamhari I, Akidah dan Ibadah, (Bandung: Pustaka Setia, 1999), hlm. 49

${ }^{11}$ Hamdani Ihsan, A. Fuad Ihsan, Filsafat Pendidikan Islam, (Bandung: Pustaka Setia, 2007), hlm. 235
} 


\section{B. Hipotesis Penelitian}

Hipotesis merupakan jawaban sementara terhadap rumusan masalah penelitian, dimana rumusan masalah penelitian telah dinyatakan dalam bentuk kalimat pernyataan. Dikatakan sementara, karena jawaban yang diberikan baru didasarkan pada teori yang relevan, belum didasarkan pada fakta-fakta empiris yang diperoleh melalui pengumpulan data. Jadi hipotesis juga dapat dinyatakan sebagai jawaban teoritis terhadap rumusan masalah penelitian, sebelum jawaban yang empirik. ${ }^{12}$

Berdasarkan kajian teori dan kerangka berpikir di atas dapatlah diajukan hipotesis, yaitu sebagai berikut:

1. Hipotesis alternatif (Ha): ada pengaruh penggunaan model pembelajaran critical incident terhadap prestasi belajar siswa pada mata pelajaran aqidah akhlak kelas III MI NW dames pokok bahasan akhlak yang terpuji tahun pelajaran 2019/2020.

2. Hiotesis $\mathrm{Nol}\left(\mathrm{H}_{0}\right)$ : tidak ada pengaruh penggunaan model pembelajaran critical incident terhadap prestasi belajar siswa pada mata pelajaran aqidah akhlak kelas III MI NW dames pokok bahasan akhlak yang terpuji tahun pelajaran $2019 / 2020$.

12 Sugiyono, Metode Penelitian Kuantitatif, Kualitatif, dan R\&D, (Bandung: Alfabeta, cet. 23, 2016), hlm. 64 


\section{METODOLOGI PENELITIAN}

\section{A. Metode dan Desain Penelitian}

Jenis penelitian ini adalah penelitian kuantitatif, karena dalam kegiatan analisisnya peneliti berhadapan dengan angka-angka yang merupakan nilai dari variabel yang diteliti.

\section{B. Teknik Pengumpulan Data}

1. Observasi adalah suatu langkah pengamatan yang dilakukan terhadap gejala atau proses (suasana) yang terjadi dalam situasi sebenarnya yang disesuaikan dengan tujuan.

2. Tes adalah alat yang digunakan untuk mengukur kemampuan seseorang setelah mengikuti proses pembelajaran, baik kemampuan dalam hal pengetahuan, sikap maupun keterampilan. ${ }^{13}$

\section{Teknik Analisis Data}

1. Uji Homogenitas

Untuk menguji homogenitas data dalam penelitan ini digunakan teknik uji Barlett. Teknik uji Barlett ini dapat digunakan untuk membuktikan homogenitas data dari beberapa sampel yang akan dianalisis dan dapat menguji dua atau lebih kelompok sampel. ${ }^{14}$

2. Uji Normalitas

Uji normalitas adalah suatu uji atau cara untuk mengetahui apakah data yang diperoleh sudah normal atau belum. Pengujian normalitas data dimaksudkan untuk mengetahui apakah data yang akan dianalisis berbentuk sebaran normal atau tidak. ${ }^{15}$

\footnotetext{
13 Toto Syatori Nasehudin dan Nanang Gozali, Metode Penelitian Kuantitatif, (Bandung: CV Pustaka Setia, 2012), hlm. 120

${ }^{14}$ Ibid, hlm. 318

${ }^{15}$ Sami’ah, "Pengaruh Penerapan Model Pembelajaran Example Non Example Terhadap Hasil Belajar Siswa Pada Mata Pelajaran IPS Terpadu Kelas VIII MTs Darul Habibi Praya Tahun Pelajaran 2014/2015”, (Skripsi, STKIP Hamzanwadi Selong, Selong, 2015), hlm. 45
} 
BADA'A: Jurnal Ilmiah Pendidikan Dasar

Vol. 2, No. 1, Juni 2020, Hal 21-34

E-ISSN: 2714-7711

\section{Hipotesis Stastistik}

Hipostesis adalah suatu jawaban yang bersifat sementara terhadap permasalahan-permasalahan penelitian, sangat terbukti melalui data yang dikumpulkan. Di dalam menentukan penerimaan dan penolakan hipotesis maka hipotesis alternatif (Ha) diubah menjadi hipotesis nol (Ho).

Untuk menguji hipotesis yang diajukan maka digunakan Uji-t, yaitu dengan cara mengolah data hasil belajar dengan menggunakan rumus uji-t pada dua pihak dengan taraf signifikan $5 \%$. 


\section{HASIL PENELITIAN DAN PEMBAHASAN}

Penelitian yang dilakukan di MI NW Dames tahun pelajaran 2019/2020 yang melibatkan siswa kelas III $^{\mathrm{A}}$ dan III $^{\mathrm{B}}$ sebagai kelas eksperimen dan kelas kontrol. Dimana penelitian ini dilakukan untuk mengetahui sejauh mana perbedaan pengaruh model pembelajaran critical incident terhadap prestasi belajar siswa.

Materi yang dibahas pada penelitian ini adalah akhlak yang terpuji. Pembelajaran ini dilakukan dalam beberapa kali pertemuan dimana pertemuan pertama digunakan untuk menguji coba instrumen soal berupa tes pilihan ganda untuk pretest dan posttest sebanyak 30 soal, agar soal tersebut valid.

Sebelum menerapkan model pembelajaran critical incident dilakukan pretest untuk selanjutnya melihat nilai dari masing-masing kelas yang diambil sebagai sampel dalam penelitian yaitu kelas III $^{\mathrm{A}}$ (kelas eksperimen) dan III $^{\mathrm{B}}$ (kelas kontrol). Kemudian dari hasil pretest nilai rata-rata dari kelas III $^{\mathrm{A}}$ adalah 60,33 dan kelas III $^{\mathrm{B}}$ nilai rata-ratanya 48,00.

Kegiatan pembelajaran pada kelas eksperimen dengan menggunakan model pembelajaran critical incident terlihat lebih baik, walaupun ada beberapa siswa masih terlihat main-main pada saat proses pembelajaran berlangsung. Siswa memahami bahwa apa yang sedang dipelajari ternyata mempunyai hubungan dengan kehidupan sehari-hari. Dengan model pembelajaran critical incident ini tidak hanya dapat melatih siswa untuk berbicara, tetapi juga dapat melatih mengingat pengalaman masa lalunya dan membuat siswa lebih aktif dalam proses belajar. Sedangkan pada kelas kontrol tidak menggunakan model pembelajaran critical incident tapi menggunakan metode ceramah dimana guru sebagai pemberi informasi dan siswa mendengarkan dan mencatat.

Sesuai dengan hasil penelitian bahwa siswa yang belajar dengan menggunakan model pembelajaran critical incident lebih baik jika dibandingkan dengan siswa yang belajar dengan tidak menggunakan model pembelajaran critical incident. Ini dapat dilihat dari prestasi belajar siswa setelah perlakuan. Pada kelas eksperimen diperoleh nilai rata-rata siswa sebesar 83,73, sedangkan 
pada kelas kontrol diperoleh nilai rata-rata 72,73. Dari data mentah tersebut sudah bisa diprediksikan bahwa perlakuan yang diberikan memberikan pengaruh positif. Setelah data posttest tersebut dianalisis dengan menggunakan uji-t, diperoleh bahwa harga $\mathrm{t}_{\text {hitung }}>\mathrm{t}_{\text {tabel }}$ yakni 2,857 > 2,048 yang artinya hipotesis Ho ditolak dan Ha diterima. Hipotesis Ha menyatakan bahwa ada pengaruh penggunaan model pembelajaran critical incident terhadap prestasi belajar siswa pada mata pelajaran Aqidah Akhlak kelas III MI NW Dames pokok bahasan akhlak yang terpuji tahun pelajaran 2019/2020.

Berdasarkan hasil analisis data dan pengujian hipotesis di atas, maka dapat disimpulkan bahwa pembelajaran IPA dengan menggunakan model pembelajaran critical incident dapat memberikan pengaruh secara positif dan signifikan terhadap prestasi belajar siswa jika di bandingkan dengan metode ceramah pada siswa kelas III MI NW Dames tahun pelajaran 2019/2020. 


\section{KESIMPULAN}

Berdasarkan hasil penelitian dari pembahasan dapat disimpulkan bahwa penerapan model pembelajaran critical incident berpengaruh terhadap prestasi belajar siswa mata pelajaran Aqidah Akhlak pokok bahasan akhlak yang terpuji kelas III MI NW Dames tahun pelajaran 2019/2020. Hal ini dibuktikan dengan nilai rata-rata posttest untuk kelas III $^{\mathrm{A}}$ (kelas eksperimen) lebih tinggi yaitu 83,73 dengan nilai tertinggi 94, dibandingkan dengan nilai rata-rata posttest kelas $\mathrm{III}^{\mathrm{B}}$ (kelas kontrol) yaitu 72,73 dengan nilai tertinggi 89. Dan hasil perhitungan uji hipotesis yaitu diperoleh harga $t_{\text {hitung }} 2,857$ dan $t_{\text {tabel }} 2,048$, artinya bahwa $t_{\text {hitung }}>$ $\mathrm{t}_{\text {tabel }}$ dengan demikian Ho ditolak dan Ha diterima. 


\section{DAFTAR PUSTAKA}

A. Zainuddin dan M. Jamhari I, Akidah dan Ibadah, Bandung: Pustaka Setia. 1999

Abdul Majid dan Dian Andayani, Pendidikan Agama Islam Berbasis Kompetensi (Konsep Implementasi Kurikulum 2004), Bandung: Remaja Rosda Karya. 2005

Ahmad Sabri, Strategi Belajar Mengajar dan Micro Teaching, Ciputat: Quantum Teaching. 2005

Dede Rosyada, Pendidikan Kewarnegaraan, Jakarta: Prenada Media.2004

H. Mahmud Yunus, Kamus Arab-Indonesia, Jakarta: PT Hidakarya Agung.1972

Hamdani Ihsan, A. Fuad Ihsan, Filsafat Pendidikan Islam, Bandung: Pustaka Setia. 2007

Hosnan, Pendekatan Saintifik dan Kontekstual dalam Pembelajaran Abad 21, cet. I, Bogor: Ghalia Indonesia.2014

Sami'ah, "Pengaruh Penerapan Model Pembelajaran Example Non Example Terhadap Hasil Belajar Siswa Pada Mata Pelajaran IPS Terpadu Kelas VIII MTs Darul Habibi Praya Tahun Pelajaran 2014/2015”, (Skripsi, STKIP Hamzanwadi Selong). 2015

Sugiyono, Metode Penelitian Kuantitatif, Kualitatif, dan $R \& D$, cet. 23. Bandung: Alfabeta. 2016

Suharsimi Arikunto, Prosedur Penelitian Suatu Pendekatan Praktik, cet. 13, Jakarta: PT Rineka Cipta. 2006

Toto Syatori Nasehudin dan Nanang Gozali, Metode Penelitian Kuantitatif, Bandung: CV Pustaka Setia. 2012

http://www.academia.edu/30501994/INCIDENT_CRITICAL, diakses 14 Juli 2019

https://syaharuddin.wordpress.com/2008/04/25/mengurangi-kebosanan-siswamelalui-berbagai-metode-mengajar/, diakses 06 Juli 2019 